JEL Classification: L 21

\title{
ФІНАНСОВО-ЕКОНОМІЧНИЙ МЕХАНІЗМ ЗАБЕЗПЕЧЕННЯ КОНКУРЕНТОСПРОМОЖНОСТІ ЯК ІНСТРУМЕНТ СТРАТЕГІЧНОГО УПРАВЛІННЯ ПІДПРИЕМСТВОМ
}

\author{
Носирсв О.О., канд. географ. наук, доцент \\ Осипова С.К., старший викладач \\ Національний технічний університет «Харківський політехнічний \\ iнституm" \\ Токар I.I., асистент \\ Харківський національний автомобільно-дорожній університет
}

Постановка проблеми. В сучасних умовах динамічного зовнішнього середовища конкурентоспроможність підприємства безпосередньо залежить від ефективності системи його стратегічного управління, що базується на принципах гнучкості, цілеспрямованості, безперервності, унікальності, результативності, ефективності тощо. Зокрема, останній з таких принципів залежить від забезпеченості й ефективності використання підприємством наявних фінансових ресурсів як елементу функціонування його фінансовоекономічного механізму. Зростаюча роль конкурентоспроможності в контексті стратегічного управління зумовлює необхідність розвитку сучасних теоретикометодичних інструментів іiї оцінки й удосконалення в боротьбі за конкурентний ринок.

Аналіз остатніх досліджень і публікацій. Загальні питання формування фінансового механізму з позиції стратегічного менеджменту знайшли своє відображення в роботах Бортнік С. М. [1], Васильціва Т.Г., Магас Н.В., Маргіта Н.О.[2], Мацьків В.В. [3], Ю. Путятина, О. Пушкаря, О. Тридіда [4, 5], та ін. Також окремі наукові напрацювання отримано в галузі формування та реалізації фінансово-економічного механізму забезпечення конкурентоспроможності. Зокрема, місце механізму забезпечення конкурентоспроможності підприємства та його продукції в структурі господарського механізму визначено в роботі Партути Т.О. й Фесенко Т.В. [6]. Принципи побудови механізму управління конкурентоспроможністю підприємств, а також стратегії фінансового забезпечення конкурентоспроможності підприємств розглянуто в роботах Т.М. Халімон $[7,8]$ i O.C. Гудзь [9]. В свою чергу, дослідженням теоретичних основ дії організаційно-економічного механізму управління конкурентоспроможністю підприємства займалися Сурженко Н.В., Агєєва I.В. [10].

Невирішені складові загальної проблеми. Не зважаючи на те, що дослідженню теоретико-методичних питань фінансового забезпечення конкурентоспроможності присвячено роботи багатьох вітчизняних науковців, 
особливої уваги за умов стійкої кризи потребує пошук ефективних шляхів реалізаціі фінансово-економічного конкурентоспроможності як інструмента стратегічного управління (СУ) підприємством.

Формулювання цілей статті. Метою статті $є$ обгрунтування наукових засад формування фінансово-економічного механізму забезпечення конкурентоспроможності підприємства 3 урахуванням структури елементів стратегічного управління, що сприятиме вишукуванню фінансових резервів іiі підвищення і зміцненню ринкових конкурентних позицій.

Виклад основного матеріалу дослідження. Безперервність процесів стратегічного розвитку підприємства зумовлює необхідність розгляду його конкурентоспроможності як динамічної категорії - об'єкта стратегічного управління, що функціонує в межах відповідної концептуальної моделі, має особливі системоутворюючі зв'язки i базується на властивостях емерджентності системи СУ в цілому. Відповідно до цього, динамічний підхід до управління означеною категорією зумовлює необхідність пошуку комбінацій iii елементів, спрямованих на отримання принципово нових властивостей стратегічної гнучкості в умовах невизначеності й мінливості зовнішнього середовища.

Отже, поняття «конкурентоспроможність підприємства» можна розглядати наступним чином. Конкурентоспроможність підприємства - це ймовірнісна здатність підприємства забезпечувати та підтримувати конкурентний потенціал господарюючого суб' єкта в стратегічному періоді, якій властиві ознаки порівнюваності, просторовості, динамічності, предметності, атрибутивності, системності та об'єктивності.

3 огляду на сучасну концепцію СУ, система принципів стратегічного управління конкурентоспроможністю включає наступний їх перелік:

- системність й комплексність формування, використання i розвитку конкурентного потенціалу підприємства;

- адаптивність як властивість, спрямована на створення нових конкурентних можливостей;

- гнучкість в площині розподілу та перегрупування стратегічних ресурсів для створення унікальних властивостей конкурентних комбінацій;

- безперервність щодо пошуків шляхів формування, використання та розвитку конкурентного потенціалу підприємства;

- синергія при комбінуванні і сполученні елементів конкурентного потенціалу ;

- холізм, який дозволяє розглядати конкурентоспроможність як єдине ціле, яке завжди є більшим, ніж проста сума ії структурних елементів;

- координація та інтеграція, виражена в високому рівні узгодженості стратегічного та оперативного управління складових конкурентоспроможності підприємства; 
- мотивація в досягненні цілей формування, забезпечення та розвитку конкурентоспроможності підприємства;

- превентивність щодо негативних наслідків зниження існуючого рівня конкурентоспроможності у складі функціональних стратегій підприємства;

- інноваційність, спрямована на пошук і створення нових конкурентних властивостей;

- когнітивність організаційних перетворень в структурі процесу управління конкурентоспроможністю підприємства при використанні стратегічних можливостей і здатностей підприємства;

- стратегічне мислення суб'єктів управління конкурентоспроможністю підприємства.

Особливе місце в процесі реалізації зазначених принципів займає фінансова складова забезпечення конкурентоспроможності, спрямована на пошук та раціональний розподіл фінансових ресурсів підприємства, що вимагає розуміння сутності функціонування ії фінансово-економічного механізму як елемента СУ. Місце та роль фінансово-економічного механізму забезпечення конкурентоспроможності підприємства у складі його стратегічного управління, визначене на засадах структурного підходу, наведено на рис 1.

Згідно графічної інтерпретації наведених складових за структурою елементів стратегічного управління, головна мета функціонування фінансовоекономічного механізму полягає у забезпеченні умов ефективного конкурування підприємства у стратегічному середовищі. При цьому функції, принципи та рівні стратегічного управління конкурентоспроможністю в фінансово-економічній площині є тотожними загально прийнятим елементам системи СУ підприємства.

В своїх витоках фінансово-економічний механізм забезпечення конкурентоспроможності підприємства започатковується за реалізації принципів цілепокладання і системності при розробці корпоративної (загальної) стратегії, що має за мету визначення загальних засад поведінки бізнес-одиниць і формування їх товарних ліній.

Надалі інтеграція фінансово-економічного механізму забезпечення конкурентоспроможності підприємства до системи стратегічного менеджменту опосередковано відбувається в межах розробки та реалізації конкурентної стратегії (бізнес-стратегіï) суб’єкта на другому рівні стратегічної ієрархії.

Цей етап передбачає активний вплив суб'єкта управління на об'єкти всіх рівнів, тобто фінансові, матеріально-технічні ресурси, виробничі і збутові процеси підприємства шляхом своєчасного забезпечення систем виробництва та маркетингу фінансовими ресурсами в межах конкурентної стратегії за рахунок власних та позикових джерел. Також управлінський вплив спрямовується на підвищення рівня конкурентоспроможності за рахунок оптимального фінансового забезпечення складових інтегрального показника за технічними, економічними, соціальними параметрами тощо. 


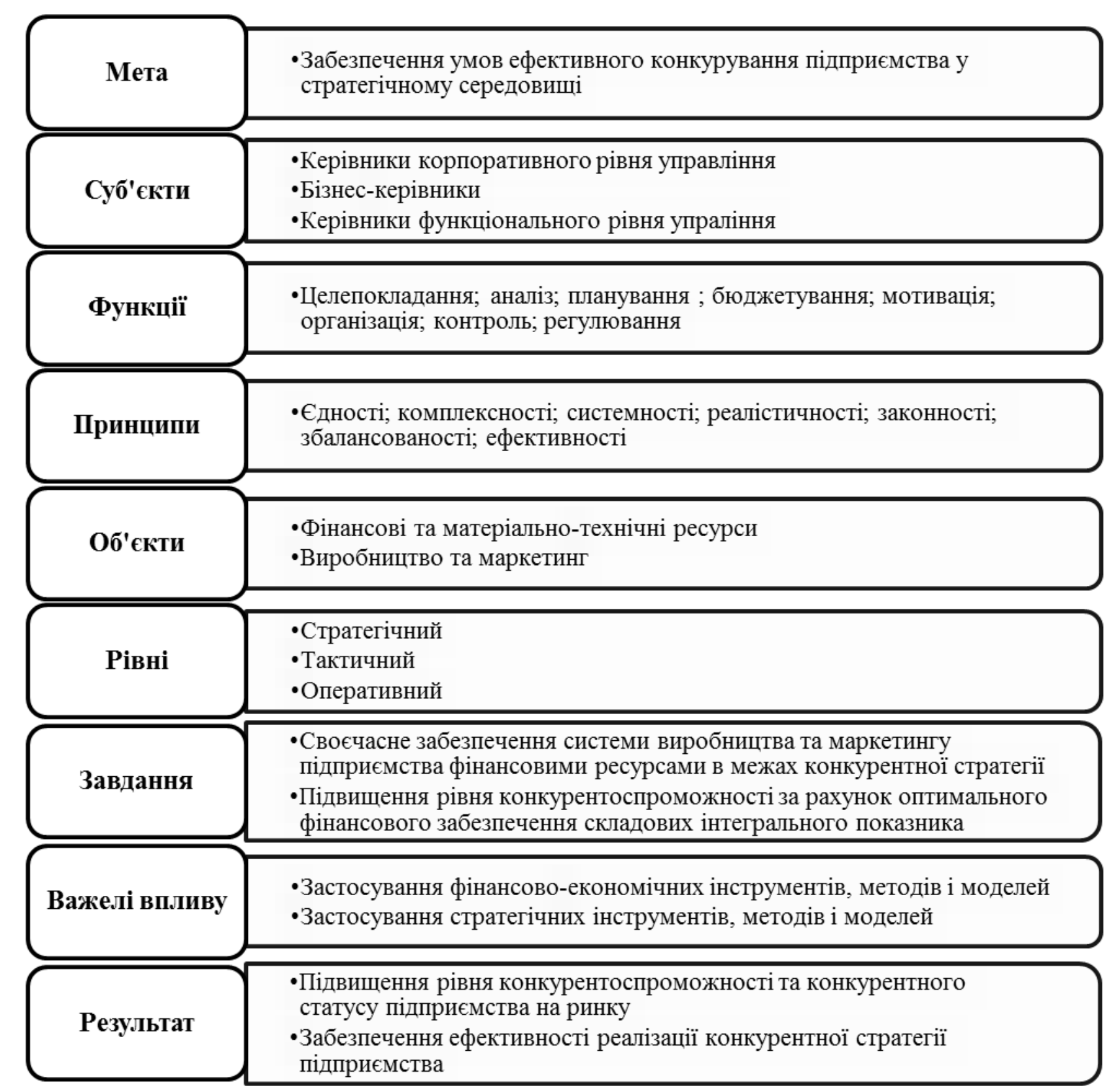

Рис. 1. Складові фінансово-економічного механізму забезпечення конкурентоспроможності підприємства за структурою елементів стратегічного управління

Джерело: авторська розробка

Підвищення рівня конкурентоспроможності й конкурентного статусу підприємства на ринку, а також забезпечення ефективності реалізації конкурентної стратегії підприємства досягається шляхом застосування фінансово-економічних й стратегічних інструментів, методів і моделей, що відносяться до оцінки рівня конкурентоспроможності, конкурентного статусу підприємства, ефективності впровадження заходів 3 підвищення конкурентоспроможності тощо. 
Таким чином, фінансово-економічний механізм забезпечення конкурентоспроможності підприємства грунтується на використанні структурного підходу до реалізації основних функцій СУ щодо підвищення іiі рівня через використання стратегічного набору фінансових інструментів, пошуку, формування, розподілу, перерозподілу та використання фінансів підприємства за фондовою спрямованістю. Це, в свою чергу, сприяє не тільки зростанню конкурентоспроможності за рахунок фінансово-економічних резервів, а й забезпеченню підприємства в цілому фінансовими ресурсами в необхідному обсязі.

Стійкими складовими такого механізму повинні бути активна співпраця всіх функціональних структур підприємства щодо вишукування додаткових джерел фінансування заходів 3 підвищення конкурентоспроможності підприємства, фінансово-економічне забезпечення розвитку конкурентоспроможності на основі підвищення фінансових можливостей підприємства, збалансованості доходів і витрат тощо.

Процедура побудови фінансово-економічного механізму забезпечення конкурентоспроможності передбачає систематизацію та впорядкування чинників зовнішнього середовища підприємства у поєднанні з чинниками його конкурентного потенціалу при розробці стратегії управління конкурентоспроможністю підприємства у складі функціональної маркетингової стратегії суб'єкта господарювання. Впровадження заходів щодо побудови фінансово-економічного механізму забезпечення конкурентоспроможності підприємства пов'язане виокремленням необхідних фінансових ресурсів із зазначенням відповідальних виконавців, що братимуть участь у його розбудові.

Висновки 3 проведеного дослідження. Таким чином, стратегічне управління конкурентоспроможністю підприємства повинне передбачати реалізацію концепції, в якій поєднуються структурний і динамічний підходи до формування і реалізації фінансово-економічного механізму ііі забезпечення. Це дає можливість установлювати мету конкурентного розвитку підприємства, здійснювати порівняння їx iз наявними фінансовими можливостями й конкурентним потенціалом, приводити їх у відповідність шляхом розробки стратегічних альтернатив, підкріплених відповідними фінансовими джерелами.

Водночас, аналіз сучасної практики застосування СУ українськими підприємствами дозволяє зробити висновок щодо відсутності використання означених підходів з боку суб'єктів управління. Отже, впровадження принципів і ідей стратегічного управління в практику фінансування заходів з підвищення конкурентоспроможності вимагає, 3 одного боку, розробки відповідного теоретичного підгрунтя, адаптованого до конкурентних ринкових умов, 3 іншого - практичного інструментарію балансування фінансової і маркетингової стратегій в стратегічному наборі підприємства.

Трактування фінансово-економічного конкурентоспроможності підприємства як інструменту управління дає можливість встановлювати фінансові цілі конкурентного 
розвитку, порівнювати їx із наявними фінансовими можливостями i конкурентним потенціалом підприємства в довгостроковому періоді, здійснювати діагностику й порівняльну оцінку конкурентоспроможності підприємства з позиції фінансових результатів діяльності, приймати рішення щодо реалізації заходів управління конкурентоспроможністю підприємства.

\section{Перелік посилань}

1. Бортнік С. М. Забезпечення конкурентної стратегії підприємства та підходи щодо ії вивчення. Науковий вісник Ужгородського національного університету. Серія: Міжнародні економічні відносини та світове господарство. 2016. № 7 C. 40-44.

2. Васильців Т. Г., Магас Н. В., Маргіта Н. О. Фінансово-економічний механізм забезпечення конкурентоспроможності роздрібних торговельних підприємств: теоретико-прикладні аспекти: монографія. Львів, 2014. 220 с.

3. Мацьків В. В. Фінансовий механізм забезпечення розвитку підприємств. Інноваиійна економіка. Науково-виробничий журнал. 2013. № 11 (49). C. 194-199.

4. Путятин Ю. А., Пушкарь А. И., Тридед А. Н. Финансовые механизмы стратегического управления развитием предприятия : монография. Харьков : Основа, 2000. 488 c.

5. Пушкарь А. И., Тридед А. Н. Разработка стратегии развития предприятия (Концепция построения организационно-экономического механизма). Бизнес Информ. Харьков. 1998. № 20. С. 65-70.

6. Партута Т. О., Фесенко Т. В. Конкурентоспроможність підприємства та механізм ії забезпечення. Інвестиції: практика та досвід. 2012. № 12. С. 91-96. URL : http://www.investplan.com.ua/pdf/12_2012/25.pdf (дата звернення : 20.10.2020).

7. Халімон T. M. Принципи побудови механізму управління конкурентоспроможністю підприємств. Науковий вісник Міжнародного гуманітарного університету. С. 158-161. URL : http://www.vestnikeconom.mgu.od.ua/journal/2017/25-1-2017/35.pdf (дата звернення : 19.10.2020).

8. Халімон Т. М. Стратегії фінансового забезпечення конкурентоспроможності підприємств. Облік і фінанси. Київ. 2016. № 4 (74). С. $126-131$.

9. Гудзь О. Є Фінансові стратегії забезпечення конкурентоспроможності підприємства. Фінансовий простір. Черкаси : ДВНЗ «Університет банківської справи». 2013. № 4 (12). С. 97-103.

10. Сурженко Н. В., Агєєва I. В. Організаційно-економічний механізм управління конкурентоспроможністю. Збірник наукових праџь Таврійського державного агротехнологічного університету (економічні науки). Мелітополь : ТДАТУ. 2014. № 1 (25). С. 232-235.

\section{References}

1. Bortnik, S. M. (2016), "Ensuring the competitive strategy of the enterprise and approaches to its study" ["Zabezpechennia konkurentnoi stratehii pidpryiemstva 
ta pidkhody shchodo yii vyvchennia"], Scientific Bulletin of Uzhhorod National University. Series: International Economic Relations and the World Economy, No 7, P. 40-44.

2. Vasyltsiv, T. G., Magas, N. V., Margita, N. O. (2014), Financial and economic mechanism of ensuring the competitiveness of retail trade enterprises: theoretical and applied aspects: monograph [Finansovo-ekonomichnyi mekhanizm zabezpechennia konkurentospromozhnosti rozdribnykh torhovelnykh pidpryiemstv: teoretyko-prykladni aspekty: monohrafiia], Lviv, $220 \mathrm{p}$.

3. Matskiv, V. V. (2013), "Financial mechanism for ensuring the development of enterprises" ["Finansovyi mekhanizm zabezpechennia rozvytku pidpryiemstv"], Innovative economy. Research and production journal, No 11 (49), P. 194-199.

4. Putyatin, Yu. A., Pushkar, A. I, Trided, A. N. (2000), Financial mechanisms of strategic management of enterprise development: monograph [Finansovyi mekhanizm zabezpechennia rozvytku pidpryiemstv], Kharkiv: Osnova, 488 p.

5. Pushkar, A. I., Trided, A. N. (1998). "Development of enterprise development strategy (Concept of construction of organizational and economic mechanism)" ["Razrabotka stratehyy razvytyia predpryiatyia (Kontseptsyia postroenyia orhanyzatsyonno-эkonomycheskoho mekhanyzma)"], Business Inform, Kharkiv, No 20, P. 65-70.

6. Partuta, T. O., Fesenko, T. V. (2012), "Competitiveness of the enterprise and the mechanism of its maintenance" ["Konkurentospromozhnist pidpryiemstva ta mekhanizm yii zabezpechennia"], Investments: practice and experience, No 12, P. 91-96, available at : http://www.investplan.com.ua/pdf/12_2012/25.pdf (last accessed 20.10.2020).

7. Halimon, T. M. "Principles of construction of the mechanism of management of competitiveness of the enterprises" ["Pryntsypy pobudovy mekhanizmu upravlinnia konkurentospromozhnistiu pidpryiemstv"], Scientific Bulletin of the International Humanities University, P. 158-161, available at : http://www.vestnik-econom.mgu.od.ua/journal/2017/25-1-2017/35.pdf (last accessed 19.10.2020).

8. Halimon, T. M. (2016), "Strategies for financial support of enterprise competitiveness" ["Stratehii finansovoho zabezpechennia konkurentospromozhnosti pidpryiemstv"], Accounting and finance, Kiev, No 4 (74), P. 126-131.

9. Gudz, O. (2013), "The financial strategies of ensure the competitiveness of the enterprise" ["Finansovi stratehii zabezpechennia konkurentospromozhnosti pidpryiemstva"], Financial space, Cherkasy: "University of Banking", No 4 (12), P. 97-103.

10. Surzhenko, N. V., Ageeva, I. V. (2014), "Organizational and economic. mechanism of competitiveness management" ["Orhanizatsiino-ekonomichnyi mekhanizm upravlinnia konkurentospromozhnistiu"]. Collection of scientific works of the Tavriya State Agrotechnological University (economic sciences), Melitopol, No 1 (25), P. 232-235. 


\section{РЕФЕРАТИ РЕФЕРАТЫ ABSTRACTS}

\section{УДК 339.137; JEL Classification: L 21}

\section{Носирсв О. О., Осипова С. К., Токар I. I. ФІНАНСОВО- ЕКОНОМІЧНИЙ МЕХАНІЗМ ЗАБЕЗПЕЧЕННЯ КОНКУРЕНТОСПРОМОЖНОСТІ ЯК ІНСТРУМЕНТ СТРАТЕГІЧНОГО УПРАВЛІННЯ ПІДПРИЕМСТВОМ}

Мета. Метою дослідження є обгрунтування наукових засад формування фінансово-економічного механізму забезпечення конкурентоспроможності підприємства 3 урахуванням структури елементів стратегічного управління, що сприятиме вишукуванню фінансових резервів іiі підвищення і зміцненню ринкових конкурентних позицій. Методика дослідження. Для досягнення зазначеної мети у роботі використано: метод теоретичного узагальнення (для визначення дефініції «конкурентоспроможність підприємства»); структурний підхід (для виокремлення складових фінансово-економічного механізму забезпечення конкурентоспроможності підприємства за структурою елементів стратегічного управління). Результати. У роботі досліджено теоретичні основи формування фінансово-економічного механізму забезпечення конкурентоспроможності підприємства. Надано визначення категорії «конкурентоспроможність підприємства» як ймовірнісної здатності підприємства забезпечувати та підтримувати конкурентний потенціал господарюючого суб'єкта в стратегічному періоді, 3 властивими ознаками порівнюваності, просторовості, динамічності, предметності, атрибутивності, системності та об'єктивності. Окремо наведено систему принципів стратегічного управління конкурентоспроможністю. Акцентовано увагу на місці фінансової складової забезпечення конкурентоспроможності в процесі реалізації зазначених принципів як такої, що спрямована на пошук та раціональний розподіл фінансових ресурсів підприємства. Запропоновано графічну інтерпретацію складових фінансово-економічного механізму забезпечення конкурентоспроможності підприємства за структурою елементів стратегічного управління. Наголошено на необхідності впровадження принципів і ідей стратегічного управління в практику фінансування заходів 3 підвищення конкурентоспроможності підприємства. Наукова новизна. Отримав подальший розвиток теоретичний підхід до стратегічного управління конкурентоспроможністю підприємства шляхом графічної інтерпретації складових фінансово-економічного механізму забезпечення його конкурентоспроможності за структурою елементів стратегічного управління, що базується на структурному підході і дозволяє встановлювати фінансові цілі конкурентного розвитку підприємства, порівнювати їx iз наявними фінансовими можливостями і конкурентним потенціалом в довгостроковому періоді, здійснювати діагностику конкурентоспроможності 3 позиції фінансових результатів, приймати рішення щодо реалізації заходів 3 iі управління. Практична значущість. Отримані результати дослідження можуть бути використані при розробці фінансової і маркетингової стратегії 
підприємства при вирішенні питань формування або підвищення існуючого рівня конкурентоспроможності.

Ключові слова: конкурентоспроможність; фінанси; забезпечення; механізм; структура; стратегія; стратегічне управління.

\section{УДК 339.137; JEL Classification: L 21}

Носырев А. А., Осипова С. К., Токарь И. И. ФИНАНСОВОЭКОНОМИЧЕСКИЙ МЕХАНИЗМ КОНКУРЕНТОСПОСОБНОСТИ КАК СТРАТЕГИЧЕСКОГО УПРАВЛЕНИЯ ПРЕДПРИЯТИЕМ

Цель. Целью исследования является обоснование научных основ формирования финансово-экономического механизма обеспечения конкурентоспособности предприятия с учетом структуры элементов стратегического управления, способствующего изысканию финансовых резервов ее повышения и укрепления рыночных конкурентных позиций. Методика исследования. Для достижения указанной цели в работе использованы: метод теоретического обобщения (для определения дефиниции «конкурентоспособность предприятия»); структурный подход (для выделения составляющих финансово-экономического механизма обеспечения конкурентоспособности предприятия по структуре элементов стратегического управления). Результаты. В работе исследованы теоретические основы формирования финансово-экономического механизма обеспечения конкурентоспособности предприятия. Дано определение категории «конкурентоспособность предприятия» как вероятностной способности предприятия обеспечивать и поддерживать конкурентный потенциал хозяйствующего субъекта в стратегическом периоде, с присущими признаками сравнительности, пространственности, динамичности, предметности, атрибутивности, системности и объективности. Отдельно определена система принципов стратегического управления конкурентоспособностью. Акцентировано внимание на месте финансовой обеспечения конкурентоспособности в процессе реализации указанных принципов, как направленной на поиск и рациональное распределение финансовых ресурсов предприятия. Предложено графическую интерпретацию составляющих финансово-экономического механизма обеспечения конкурентоспособности предприятия по структуре элементов стратегического управления. Отмечена необходимость внедрения принципов и идей стратегического управления в практику финансирования мероприятий по повышению конкурентоспособности предприятия. Научная новизна. Получил дальнейшее развитие теоретический подход к стратегическому управлению конкурентоспособностью предприятия путем графической интерпретации составляющих финансово-экономического механизма обеспечения его конкурентоспособности по структуре элементов стратегического управления, основанный на структурном подходе и позволяющий устанавливать финансовые цели конкурентного развития предприятия, сравнивать их с 
имеющимися финансовыми возможностями и конкурентным потенциалом в долгосрочном периоде, осуществлять диагностику конкурентоспособности с позиции финансовых результатов, принимать решение о реализации мероприятий по ее управлению. Практическая значимость. Полученные результаты исследования могут быть использованы при разработке финансовой и маркетинговой стратегии предприятия при решении вопросов формирования или повышение существующего уровня конкурентоспособности.

Ключевые слова: конкурентоспособность; финансы; обеспечение; механизм; структура; стратегия; стратегическое управление.

\section{UDC 339.137; JEL Classification: L 21}

Nosyriev O., Osypova S., Tokar I. FINANCIAL AND ECONOMIC MECHANISM FOR COMPETITIVENESS PROVIDING AS A TOOL OF STRATEGIC ENTERPRISE MANAGEMENT

Purpose. The purpose of the article is to substantiate the scientific basis for the formation of financial and economic mechanism for competitiveness of an enterprise, taking into account the structure of strategic management elements, which will help to find financial reserves for its increase and strengthen market competitive positions.

Methodology of research. The following methods were used in the research. The method of theoretical generalization was relevance for determination the definition of "enterprise competitiveness". Structural approach was applied to identify the components of the financial and economic mechanism for providing the competitiveness of the enterprise according to the structure of strategic management elements. Findings. The theoretical bases of formation of the financial and economic mechanism for providing the competitiveness of the enterprise were researched in article. The definition of the category "enterprise competitiveness" as the probabilistic ability of an enterprise to provide and maintain the competitive potential in a strategic period was suggested. It contains the inherent features of comparability, spatiality, dynamism, objectivity, attributability, systematicity and objectivity. A system of principles of strategic competitiveness management is presented separately. Attention is focused on the place of the financial component for providing the competitiveness in the process of implementing these principles. This place consists in finding a rational distribution of financial resources of the enterprise. The graphical interpretation of the financial and economic mechanism components for providing the competitiveness of the enterprise of the strategic management on structure elements is proposed. The necessity of implementing the principles and ideas of strategic management in the practice of financing to improve the competitiveness of the enterprise was noted. Originality. The theoretical approach to strategic management of enterprise competitiveness was further developed by graphical interpretation of financial and economic mechanism components for providing the competitiveness at structure elements of strategic management. It is based on a structural approach and allows setting financial goals for the competitive development of the enterprise. It also allows comparing them with the available financial opportunities and competitive potential in the long term, diagnosing 
competitiveness from the standpoint of financial results, making decisions on the implementation of measures for its management. Practical value. The results of the study can be used in the development of financial and marketing strategy of the enterprise in addressing the formation or improvement of the existing level of competitiveness.

Key words: competitiveness; finance; providing; mechanism; structure; strategy; strategic management.

Відомості про авторів / Сведения об авторах / About the Authors

Носирєв Олександр Олександрович - кандидат географічних наук, доцент, Національний технічний університет «Харківський політехнічний інститут», доцент кафедри міжнародного бізнесу та фінансів, м. Харків, Україна; e-mail: nosyriev.bf@khpi.edu.ua; ORCID ID: http://orcid.org/0000-00034089-3336. моб. 066-716-70-27.

Носырев Александр Александрович - кандидат географических наук, доцент, Национальный технический университет «Харьковский политехнический інститут», доцент кафедры международного бизнеса и финансов, г. Харьков, Украина; e-mail: nosyriev.bf@khpi.edu.ua; ORCID ID: http://orcid.org/0000-0003-4089-3336. моб. 066-716-70-27.

Nosyriev Oleksandr - PhD, Associate Professor, National Technical University "Kharkiv Polytechnic Institute", Associate Professor of the Department of International Business and Finance, Kharkiv, Ukraine.

Осипова Світлана Костянтинівна - Національний технічний університет «Харківський політехнічний інститут», старший викладач кафедри міжнародного бізнесу та фінансів, м. Харків, Україна; е-mail: osipovask1@ukr.net; ORCID ID: http://orcid.org/0000-0002-2381-1901 Моб. 097894-47-07.

Осипова Светлана Константиновна - Национальный технический университет «Харьковский политехнический институт», старший преподаватель кафедры международного бизнеса и финансов, г. Харьков, Украина; e-mail: osipovask1 @ukr.net; ORCID ID: http://orcid.org/0000-0002-23811901. Моб. 097-894-47-07.

Osypova Svitlana - National Technical University «Kharkiv Polytechnic Institute», Senior Lecturer of the Department of International Business and Finance, Kharkiv, Ukraine.

Токар Інна Іванівна - асистент кафедри економіки і підприємництва, Харківський національний автомобільно-дорожній університет, м. Харків, Україна; e-mail: tokar_innaiv@ukr.net; ORCID: https://orcid.org/0000-0002-52871751. Моб. 050-274-97-99.

Токарь Инна Ивановна - ассистент кафедры экономики и предпринимательства, Харьковский национальный автомобильно-дорожный университет, г. Харьков, Украина.

Tokar Inna - Associate at the Department of Economics and Entrepreneurship, Kharkiv National Automobile and Highway University, Kharkiv, Ukraine. 